\title{
Fatal yellow phosphorus poisoning in a child
}

\author{
*K Jagadish Kumar ${ }^{1}$, M Santhosh Kumar ${ }^{1}$, Divya Sankuru ${ }^{1}$, Nandakishore Reddy ${ }^{1}$ \\ Sri Lanka Journal of Child Health, 2018; 47: 273-275 \\ DOI: http://dx.doi.org/10.4038/sljch.v47i3.8553 \\ (Keywords: Yellow phosphorous, poisoning, hepatic failure, multisystem involvement)
}

\begin{abstract}
Introduction
Yellow (white) phosphorus is a poison which involves the gastrointestinal, hepatic, cardiovascular, nervous and renal systems ${ }^{1}$. It is used in fireworks and as rodenticides $^{2}$. Rodenticides are available as pastes containing 2 to $5 \%$ of yellow phosphorus ${ }^{1}$. Ratol is a commonly used rodenticide in Indian houses and contain 3\% yellow phosphorus ${ }^{3}$. We present a case of acute yellow phosphorus poisoning in a 15 year old girl with suicidal intention that led to multi-organ failure and death.
\end{abstract}

\section{Case report}

A 15 year-old girl was brought with a history of consumption of a whole rodenticide paste tube Ratol, containing 3\% yellow phosphorus. She was first admitted to a local hospital with gastrointestinal symptoms and weakness on the day of consumption and referred to our hospital after 48 hours. There was no history of altered sensorium, convulsions or oliguria.

On admission, the child was conscious (Glasgow coma scale $15 / 15)$, icteric with a temperature of $98^{\circ} \mathrm{F}$, pulse rate (PR) 122/minute, respiratory rate (RR) 32/minute, blood pressure (BP) 90/70 $\mathrm{mm} \mathrm{Hg}$ and oxygen saturation $\left(\mathrm{SpO}_{2}\right) \quad 96 \%$ in room air. Abdominal examination revealed a $4 \mathrm{~cm}$ hepatomegaly. Stomach wash was given. Inj. ceftriaxone and Inj. vitamin $\mathrm{K}$ were given and she was commenced on $\mathrm{N}$-acetyl cysteine.

On day 2 of admission, her BP started falling accompanied by cold peripheries because of peripheral collapse. Normal saline boluses $(20 \mathrm{ml} / \mathrm{kg})$ were given thrice followed by dopamine $10 \mu \mathrm{g} / \mathrm{kg} /$ minute. Her blood sugar was monitored. She was conscious but was talking incoherently. Her BP improved and maintenance

${ }^{1}$ JSS Medical College, JSS University, Mysore, India

*Correspondence: jagdishmandya@gmail.com

(Received on 09 January 2017: Accepted after revision on 20 February 2017)

The authors declare that there are no conflicts of interest Personal funding was used for the project.

Open Access Article published under the Creative Commons Attribution CC-BY (C) (P) intravenous fluids were given. Her PR was 90/min, BP $94 / 68 \mathrm{~mm} \mathrm{Hg}$, RR 20/min, $\mathrm{SpO}_{2} 100 \%$ in room air, capillary filling time (CFT) less than 3 seconds, warm peripheries with IV Fluids at $5 \mathrm{ml} / \mathrm{kg} / \mathrm{hr}$. Arterial blood gases $(\mathrm{ABG})$ revealed a $\mathrm{pH}$ of 7.35 , a bicarbonate level of $9.7 \mathrm{mEq} / \mathrm{L}$ and a base excess of -13.9. Therefore a slow bicarbonate infusion was started.

On day 3 of admission, her BP started to fall again and she developed hypotension in spite of dopamine infusion. Therefore, epinephrine infusion 0.1 $\mu \mathrm{g} / \mathrm{kg} / \mathrm{minute}$ was started. She was noted to be irritable, oriented, with a HR of 138/minute, RR of 32/minute, $\mathrm{SpO}_{2}$ of $98 \%$ and $\mathrm{BP} 92 / 70 \mathrm{~mm} \mathrm{Hg}$. Abdominal examination revealed a $4 \mathrm{~cm}$ hepatomegaly. Her 2D echocardiogram was normal. Her blood sugar was maintained normally. The electrocardiogram (ECG) showed ST wave depression. Her prothrombin time (PT) and activated partial thromboplastin time (APTT) were prolonged and therefore, fresh frozen plasma was given.

On day 4 of admission, in spite of dopamine and epinephrine, her BP started decreasing and noradrenaline infusion was started. She was febrile with a RR of 34/minute and a BP of 90/48mm of $\mathrm{Hg}$. Her sensorium started deteriorating (GCS 10/15). Her RR was $58 /$ minute, BP $84 / 50 \mathrm{~mm} \mathrm{Hg}$ while on 3 inotropes, $\mathrm{SpO}_{2} 88 \%$ with 5 litres of oxygen. The chest $\mathrm{X}$ - ray showed bilateral parenchymal infiltration. Dobutamine infusion $10 \mu \mathrm{g} / \mathrm{kg} /$ minute was started. She was also given IV piperacillin and tazobactum. ABG revealed hypoxia. Child was put on mechanical ventilator with PRVC mode.

On day 5 of admission, she was still on the mechanical ventilator with PRVC mode. She was having tachycardia (PR 146/minute) and BP was 80/40mm Hg while on 4 inotropes. Her adrenalin dose was increased up to $0.5 \mu \mathrm{g} / \mathrm{kg} /$ minute. In spite of ventilator and 4 inotropes to support the systemic circulation, child deteriorated and expired.

Investigations carried out during the 5 days are shown in Table 1. 
Table 1: Investigations

\begin{tabular}{|c|c|c|c|c|c|}
\hline Investigation & Day 1 & Day 2 & Day 3 & Day 4 & Day 5 \\
\hline Haemoglobin $(\mathrm{g} / \mathrm{dL})$ & 12 & 14 & & & 14 \\
\hline Total white cell count (/cu mm) & 2700 & 2610 & & & 6880 \\
\hline Platelet count (/ cu mm) & 1.052 & 1.53 & & & 90000 \\
\hline Packed cell volume & 36.3 & 42.8 & & & \\
\hline Blood sugar $(\mathrm{mg} / \mathrm{dL})$ & 109 & 366 & & & \\
\hline Bilirubin (Total \& direct) mg/dL & $1.14 / 0.27$ & & $3.01 / 1.28$ & & $3.9 / 3.6$ \\
\hline Sodium $(\mathrm{mmol} / \mathrm{L})$ & 128 & 130 & 133 & 133 & 132 \\
\hline Potassium $(\mathrm{mmol} / \mathrm{L})$ & 3 & 2.5 & 2.5 & 2.9 & 3.8 \\
\hline Chloride $(\mathrm{mmol} / \mathrm{L})$ & 96 & & 91 & 91 & 100 \\
\hline Urea (mg/dL) & 40 & 44 & 49 & & 29 \\
\hline Creatinine $(\mathrm{mg} / \mathrm{dL})$ & 0.8 & 1 & 1 & & 0.8 \\
\hline Calcium (mg/dL) & 7.5 & 8.7 & & & \\
\hline Prothrombin time (seconds) /INR & $25.3 / 1.95$ & $54 / 1.88$ & $64 / 4.57$ & & $46 / 4.02$ \\
\hline $\begin{array}{l}\text { Activated partial thromboplastin } \\
\text { time (seconds) }\end{array}$ & 33 & 39.2 & 46 & & 46.5 \\
\hline Aspartate transaminase $(\mathrm{U} / \mathrm{L})$ & 47 & 958 & 755 & & 135 \\
\hline Alanine transaminase $(\mathrm{U} / \mathrm{L})$ & 33 & 659 & 834 & & 292 \\
\hline Alkaline Phosphatase (U/L) & 151 & & & & \\
\hline Magnesium (mg/dL) & & 2.3 & 2.83 & & \\
\hline $\begin{array}{l}\text { CK-MB }(\mathrm{ng} / \mathrm{mL}) \\
\text { (Normal 1-7) }\end{array}$ & & 4.86 & 6.47 & & \\
\hline $\begin{array}{l}\text { Troponin-T(ng/mL) } \\
\text { (Normal 0.0001-0.0249) }\end{array}$ & & & 0.067 & & \\
\hline Echocardiography & & $\begin{array}{l}\text { Normal; Ejection } \\
\text { fraction } 60 \% \\
\end{array}$ & Normal & & \\
\hline ECG & & Normal & $\begin{array}{c}\text { Sinus } \\
\text { tachycardia, } \\
\text { ST wave } \\
\text { depression }\end{array}$ & $\begin{array}{c}\text { Sinus } \\
\text { tachycardia, } \\
\text { ST wave } \\
\text { depression }\end{array}$ & \\
\hline Chest X-RAY & Normal & & Normal & $\begin{array}{c}\text { Bilateral } \\
\text { parenchymal } \\
\text { infiltration }\end{array}$ & $\begin{array}{c}\text { Bilateral } \\
\text { pneumonia }\end{array}$ \\
\hline $\begin{array}{l}\text { Arterial Blood Gas } \\
\mathrm{pH}\end{array}$ & 7.39 & 7.35 & 7.26 & 7.49 & 7.21 \\
\hline $\mathrm{Pao} 2$ & 120 & 85.1 & 70.3 & 93 & 62.4 \\
\hline $\mathrm{PaCo} 2$ & 22.2 & 17.8 & 23.5 & 22.5 & 25.2 \\
\hline Bicarbonate & 13.3 & 9.7 & 10.2 & 16.8 & 9.7 \\
\hline Base Excess & -9.9 & -13.9 & -15.2 & -6.1 & -16.7 \\
\hline Lactate & 5.6 & 3.2 & 5.7 & & 7.5 \\
\hline Ionic $\mathrm{Ca}$ & 0.72 & 1.27 & 2.09 & 0. & \\
\hline
\end{tabular}

\section{Discussion}

Yellow phosphorus is a general protoplasmic poison which causes multi-organ failure ${ }^{1}$. The patient passes through three stages. In the first stage, which occurs during the first 24 hours, patient is either asymptomatic or has signs and symptoms of gastrointestinal irritation. The second stage occurs between 24 to 72 hours during which the patient may be asymptomatic and be discharged prematurely. There may be mild elevation of liver enzymes and bilirubin in this stage. The third stage occurs after 72 hours with acute hepatic failure and coagulopathy, until the resolution of symptoms or death $^{1}$.

The child reported here had the classical presentation. During the first 48 hours she developed only gastrointestinal symptoms as described. She progressed to acute liver cell failure on the $3^{\text {rd }}$ day of ingestion and was started on $\mathrm{N}$-acetyl cysteine. A few studies have shown improvement with $\mathrm{N}$-acetyl cysteine ${ }^{4}$. Our case succumbed to multi-organ failure. From the day of admission our patient had leucopenia and thrombocytopenia. Basheer et al reported severe leucopenia along with neutropenia secondary to selective myelosuppression in a 14-year-old girl following ingestion of yellow phosphorus but her platelet counts were normal ${ }^{5}$. Cardiac involvement includes hypotension, tachycardia, arrhythmias and cardiogenic shock ${ }^{1,3}$. Severe hypotension has been observed as one of the major clinical features ${ }^{4}$. Our child too had tachycardia, increased troponin levels along with ECG findings (ST wave depression) and inotropes resistant shock. In a study from Ecuador, out of 85 patients, arrhythmias were noted in only 5 of them. They observed ECG changes such as altered or inverted $\mathrm{T}$ waves, QRS complex changes, tachycardia, 
arrhythmias, atrial fibrillation and decreased ventricular contractility $^{2}$. Central nervous system effects include changes in mental status like confusion, psychosis, hallucinations, and coma ${ }^{1}$. Our patient was confused with irrelevant talk on the third day. Gonzalez-Andrade et al reported gastrointestinal symptoms in $71 \%$ of patients, jaundice and hyperbilirubinemia in $37 \%$, increased liver enzymes in $32 \%$, prolonged coagulation time in $18 \%$ and hypoglycaemia in $13 \%$ of patients. They concluded the bad prognostic factors as high dose, late medical attention (after 3 days), coma, hypoglycaemia and metabolic acidosis ${ }^{2}$. In our child the poor prognostic factors were probably high dose and metabolic acidosis.

A dose of more than $1 \mathrm{mg} / \mathrm{kg}$ of yellow phosphorus is almost invariably fatal and our child had ingested $35 \mathrm{~g}$ of ratol $^{2,4}$. Ratol is a cheap, easily available over the counter rat poison, commonly mistaken for toothpaste and consumed by children ${ }^{3}$. The best methods to overcome yellow phosphorus poisoning would be increase public awareness and ban the sale of these fatal poison containing preparations as suggested by Mohideen et $a l^{3}$.

\section{References}

1. Mauskar A, Mehta K, Nagotkar L, Shanbag P. Acute hepatic failure due to yellow phosphorus ingestion. Indian Journal of Pharmacology 2011; 43:355-6. https://doi.org/10.4103/0253-7613.81500 PMid: 21713048 PMCid: PMC3113395
2. Fabrico Gonzalez-Andrade, Ramiro LopezPulles. White phosphorous poisoning by oral ingestion of fire crackers or little devils: Current experience in Ecuador. Clinical Toxicology 2011; 49:29-33. https://doi.org/10.3109/15563650.2010.54786 0

PMid: 21288149

3. Mohideen S K, Kumar K S. Should ratol paste be banned? Indian Journal of Critical Care Medicine 2015; 19:128-9.

https://doi.org/10.4103/0972-5229.151026

PMid: 25722560 PMCid: PMC4339902

4. Sleeba S, Raj M, Kabeer P,Dipu K P. A rare case of yellow phosphorous poisoning with acute cholestatic hepatitis, bicytopenia and impending hepatic failure. International Journal of Pharmacy and Pharmaceutical Sciences 2016; 8: 402-3.

5. Basheer A, Mookkappan S, Padhi S, Iqbal N. Selective myelosuppression following yellow phosphorus ingestion. Australasian Medical Journal 2015; 8:19-23.

https://doi.org/10.4066/AMJ.2015.2241

PMid: 25848404 PMCid: PMC4321199 